\title{
New Dammarane Triterpenoids, Caffruones A-D, from the Cherries of Coffea arabica
}

\author{
Xia Wang ${ }^{1,2} \cdot$ Xing-Rong Peng $^{1} \cdot$ Jing $\mathrm{Lu}^{1,2} \cdot$ Gui-Lin $\mathrm{Hu}^{1,2} \cdot$ Ming-Hua Qiu ${ }^{1,2}$
}

Received: 13 April 2018/Accepted: 9 July 2018/Published online: 20 August 2018

(C) The Author(s) 2018

\section{Abstract}

In present study, four new dammarane-type triterpenoids, namely caffruones A-D (1-4), were isolated from the cherries of Coffea arabica. Their structures were elucidated by extensive spectroscopic analysis including 1D, 2D NMR (HSQC, HMBC, ${ }^{1} \mathrm{H}-{ }^{1} \mathrm{H}$ COSY, and ROESY), HRMS and IR spectra. This is the first time that tetracyclic triterpenes have been reported in genus Coffea.

\section{Graphical Abstract}

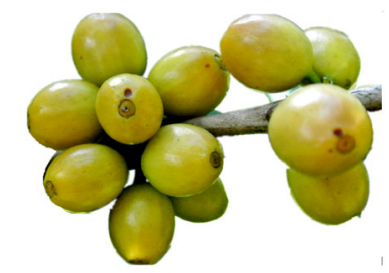

Cherries of Coffea arabica

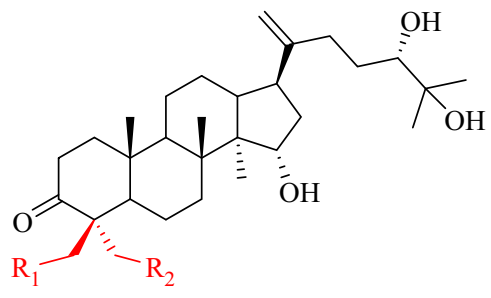

$1 \mathrm{R}_{1}=\mathrm{H} \quad \mathrm{R}_{2}=\mathrm{OH}$

$2 \mathrm{R}_{1}=\mathrm{OH} \quad \mathrm{R}_{2}=\mathrm{H}$<smiles>[R]CC1(C[R])C(=O)CC[C@]2(C)[C@@H]3CC[C@H]4[C@@H](C(=C)CCC=C(CO)CO)C[C@H](O)[C@]4(C)[C@H]3CC[C@@]12C</smiles>

$3 \mathrm{R}_{1}=\mathrm{OH} \quad \mathrm{R}_{2}=\mathrm{H}$

$4 \mathrm{R}_{1}=\mathrm{H} \quad \mathrm{R}_{2}=\mathrm{OH}$

Keywords Coffea arabica · Cherries · Triterpenoids · Structural elucidation

Electronic supplementary material The online version of this article (https://doi.org/10.1007/s13659-018-0181-y) contains supplementary material, which is available to authorized users.

Ming-Hua Qiu

mhchiu@mail.kib.ac.cn

1 State Key Laboratory of Phytochemistry and Plant Resources in West China, Kunming Institute of Botany, Chinese Academy of Sciences, Kunming 650201, People's Republic of China

2 University of the Chinese Academy of Sciences, Beijing 100049, People's Republic of China

\section{Introduction}

Coffea arabica L. (Rubiaceae) is the most economic significant species in the coffee trade, occupying $69 \%$ of the world's coffee production [1]. Yunnan province is the main cultivation base of coffee in China, and the cultivated species is almost $C$. arabica. In 2016, the total coffee production of Yunnan province was nearly 140 thousand tons [2]. Research found that coffee consumption has a variety of beneficial effects on human health, like antiAlzheimer's disease [3], anti-diabetes [4] and anti-cancers [5]. Previous phytochemical investigations on green and roasted coffee beans have resulted in the isolation of caffeine, trigonelline, chlorogenic acids, phenolic acids and a series of ent-kaurane diterpenoids [6-8]. All of them contributed to the healthy functions of coffee brews $[9,10]$. However, to our best knowledge, there is no research has 

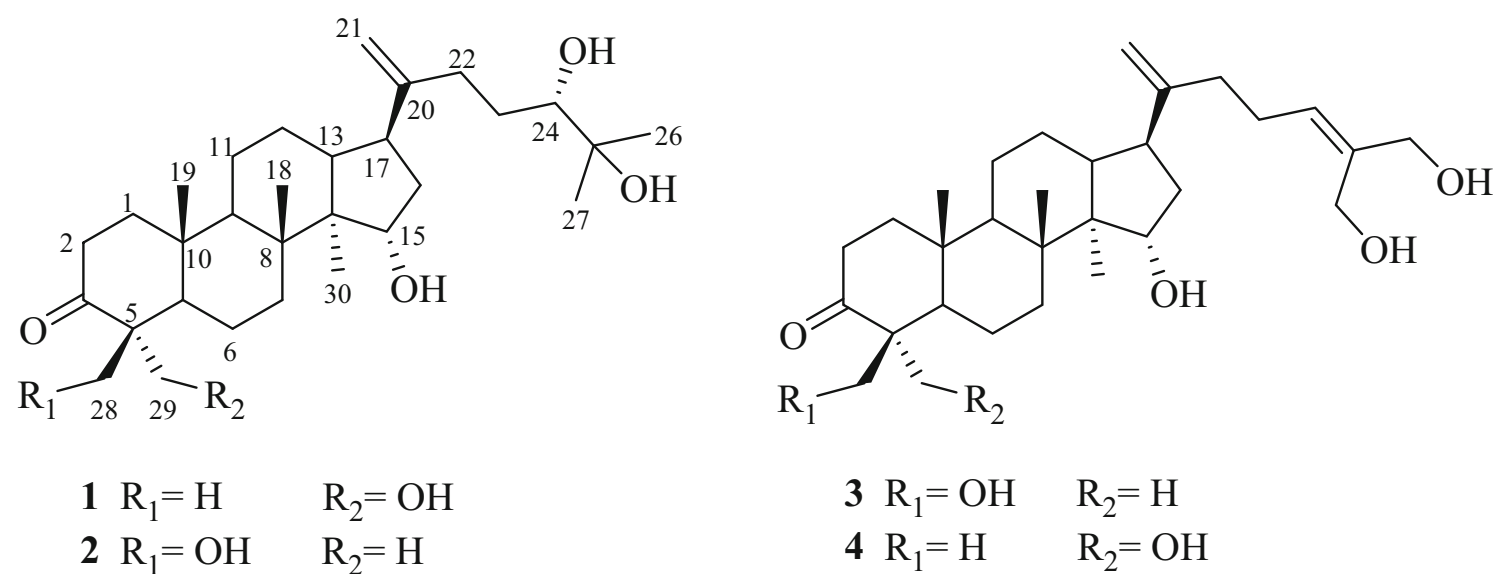

Fig. 1 Structures of caffruones A-D (1-4) isolated from the cherries of Coffea arabica

been focused on the chemical constituents of the coffee cherries. Therefore, as part of our systematic phytochemical investigation on $C$. arabica cultivated in Yunnan province, we isolated four new dammarane triterpenoids (1-4) (Fig. 1) from the coffee cherries. This is the first time that dammarane triterpenoids have been reported in genus Coffea. Herein, the isolation and structural elucidation of all isolates were described.

\section{Results and Discussion}

The methanol extract of air-dried coffee cherries was subjected to multiple chromatographic steps, involving silica gel column chromatography, preparative thin-layer chromatography (P-TLC) and semi-preparative HPLC to yield four dammarane triterpenoids (1-4).

Caffruone A (1) was isolated as white amorphous powder and the molecular formula $\mathrm{C}_{30} \mathrm{H}_{50} \mathrm{O}_{5}$ was deduced from its $[\mathrm{M}+\mathrm{Na}]^{+}$ion peak at $\mathrm{m} / z 513.3551$ (calcd 513.3550), with six degrees of unsaturation. The ${ }^{1} \mathrm{H}$ NMR spectrum (Table 1) exhibited the proton signals for six singlet methyls $\left(\delta_{\mathrm{H}} 0.95,1.01,1.06,1.12,1.17,1.23\right)$, one olefinic methylene $\left[\left(\delta_{\mathrm{H}} 4.78, \mathrm{~s}, \mathrm{H}-21 \mathrm{a}\right),\left(\delta_{\mathrm{H}} 4.74, \mathrm{~d}\right.\right.$, $J=1.8 \mathrm{~Hz}, \mathrm{H}-21 \mathrm{~b})]$, one oxygenated methylene $\left[\left(\delta_{\mathrm{H}} 3.43\right.\right.$, 3.38 ), each $1 \mathrm{H}, J=11.3 \mathrm{~Hz}, \mathrm{H}-28 \mathrm{a}$ and $\mathrm{H}-28 \mathrm{~b}]$ and two oxygenated methines $\left[\left(\delta_{\mathrm{H}} 3.38(\mathrm{dd}, J=10.6\right.\right.$ and $1.9 \mathrm{~Hz}$, $\left.\mathrm{H}-24), \delta_{\mathrm{H}} 4.28(\mathrm{t}, J=8.6 \mathrm{~Hz}, \mathrm{H}-15)\right]$. The ${ }^{13} \mathrm{C}$-DEPT NMR spectra (Table 2) suggested that $\mathbf{1}$ was a triterpenoid derivative with a total 30 carbons, consisiting of six methyls, eleven methylenes (one oxygenated and one olefinic), six methines (two oxygenated) and seven quaternary carbons (one oxygenated, one olefinic and one ketone carbonyl). Apart from a double bond and a carbonyl groups, the remaining elements of unsaturation degrees contributed to four rings, therefore, 1 should be a tetracyclic triterpenoid.
Furthermore, the key HMBC correlations (Fig. 2) from $\mathrm{H}_{3}-18\left(\delta_{\mathrm{H}} 1.12\right)$ to $\mathrm{C}-7\left(\delta_{\mathrm{C}} 35.4\right), \mathrm{C}-14\left(\delta_{\mathrm{C}} 50.4\right)$ and $\mathrm{C}-8$ $\left(\delta_{\mathrm{C}} 40.7\right)$, from $\mathrm{H}_{2}-7\left(\delta_{\mathrm{H}} 1.70,1.56\right)$ to $\mathrm{C}-8$ and $\mathrm{C}-18\left(\delta_{\mathrm{C}}\right.$ 15.6), from $\delta_{\mathrm{H}} 1.43(\mathrm{H}-9)$ to $\mathrm{C}-18$, and from $\mathrm{H}_{3}-19\left(\delta_{\mathrm{H}}\right.$ $1.43)$ to $\mathrm{C}-9\left(\delta_{\mathrm{C}} 50.5\right), \mathrm{C}-10\left(\delta_{\mathrm{C}} 36.8\right)$ and $\mathrm{C}-1\left(\delta_{\mathrm{C}} 39.6\right)$, demonstrated that $\mathrm{C}-8$ and $\mathrm{C}-10$ in $\mathbf{1}$ were substituted by methyls (Fig. 2). Moreover, the ROESY correlations of $\delta_{\mathrm{H}}$ $1.70(\mathrm{H}-7 \mathrm{a}) / \delta_{\mathrm{H}} 0.96\left(\mathrm{H}_{3}-30, \alpha\right.$-oriented $), \delta_{\mathrm{H}} 1.56(\mathrm{H}-7 \mathrm{~b}) / \delta_{\mathrm{H}}$ $1.12\left(\mathrm{H}_{3}-18\right) / \delta_{\mathrm{H}} 1.71(\mathrm{H}-13)$ and $\delta_{\mathrm{H}} 2.25(\mathrm{H}-17) / \delta_{\mathrm{H}} 0.96$ $\left(\mathrm{H}_{3}-30\right)$ confirmed that $\mathrm{H}_{3}-18, \mathrm{H}-13$ were $\beta$-oriented and $\mathrm{H}-17$ was $\alpha$-oriented in $\mathbf{1}$ (Fig. 2). The evidence described above enabled the establishment of dammarane triterpene skeleton of $\mathbf{1}$ [11, 12].

Aforementioned information suggested that the structure of 1 were closely resembled to 24,25-dihydroxy-dammar20-en-3-one [13], except that a methyl and an aliphatic methylene in the latter were replaced by an oxygented methylene $\left(\delta_{\mathrm{C}} 66.8\right)$ and an oxygenated methine $\left(\delta_{\mathrm{C}} 73.8\right)$ in $\mathbf{1}$, respectively. The HMBC correlations from the methylene protons $\left(\delta_{\mathrm{H}} 3.43,3.64, \mathrm{H}_{2}-28\right)$ to $\mathrm{C}-3\left(\delta_{\mathrm{C}}\right.$ $219.0), \mathrm{C}-4\left(\delta_{\mathrm{C}} 52.4\right)$ and $\mathrm{C}-29\left(\delta_{\mathrm{C}} 16.6\right)$, together with the ROESY correlation of $\mathrm{H}_{2}-28 / \mathrm{H}-5$ indicated that C-28 in 1 was connected a hydroxyl group (Fig. 2). Meanwhile, the HMBC correlations from $\mathrm{H}_{3}-30\left(\delta_{\mathrm{H}} 0.95\right)$ to the methine carbon $\left(\delta_{\mathrm{C}} 73.8, \mathrm{C}-15\right)$ and ${ }^{1} \mathrm{H}^{1}{ }^{1} \mathrm{H}$ COSY correlations between $\delta_{\mathrm{H}} 1.89,1.68\left(\mathrm{H}_{2}-16\right) / \delta_{\mathrm{H}} 4.28(\mathrm{H}-15)$ confirmed a hydroxyl group was located at $\mathrm{C}-15$ in $\mathbf{1}$.

Attempts to determine the absolute configuration of the 24,25-diol moiety in $\mathbf{1}$ by X-ray crystallography, Snatzke's method and modified Mosher's method were failed. However, on the analysis of the literatures available [14-17], the ${ }^{1} \mathrm{H}$ and ${ }^{13} \mathrm{C}$ NMR chemical shifts for two stereochemical configuration at C-24 of triterpenes with 24,25-diol moeity were distinct different. The $24 S$ and $24 R$ epimers of 24,25-dihydroxytiruall-7-en-3-one exhibited the chemical shifts of $\delta 3.32 / 78.6(24 S)$ and $\delta 3.29 /$ $79.5(24 R)$ [14], respectively. Thus, the chemical signals of 
Table $1{ }^{1} \mathrm{H}$ NMR spectroscopic data of compounds $\mathbf{1 - 4}[\delta$ in ppm, $J$ in $\mathrm{Hz}]$

\begin{tabular}{|c|c|c|c|c|}
\hline Position & $\mathbf{1}^{\mathrm{a}}$ & $2^{\mathrm{a}}$ & $3^{\mathrm{a}}$ & $4^{a}$ \\
\hline 1 & $2.01(\mathrm{~m}), 1.40(\mathrm{~m})$ & $1.93(\mathrm{~m}), 1.57(\mathrm{~m})$ & $1.93(\mathrm{~m}), 1.57(\mathrm{~m})$ & $2.01(\mathrm{~m}), 1.40(\mathrm{~m})$ \\
\hline 2 & $2.62(\mathrm{~m}), 2.30(\mathrm{~m})$ & $2.59(\mathrm{~m}), 2.38(\mathrm{~m})$ & $2.59(\mathrm{~m}), 2.38(\mathrm{~m})$ & $2.62(\mathrm{~m}), 1.70(\mathrm{~m})$ \\
\hline 3 & - & - & - & - \\
\hline 4 & - & - & - & - \\
\hline 5 & $1.67(\mathrm{~m})$ & $1.63(\mathrm{~m})$ & $1.64(\mathrm{~m})$ & $1.67(\mathrm{~m})$ \\
\hline 6 & $1.42(\mathrm{~m}), 1.57(\mathrm{~m})$ & $1.62(\mathrm{~m}), 1.50(\mathrm{~m})$ & $1.63(\mathrm{~m}), 1.58(\mathrm{~m})$ & $1.56(\mathrm{~m}), 1.41(\mathrm{~m})$ \\
\hline 7 & $1.70(\mathrm{~m}), 1.56(\mathrm{~m})$ & $1.60(\mathrm{~m}), 1.47(\mathrm{~m})$ & $1.59(\mathrm{~m}), 1.48(\mathrm{~m})$ & $2.31(\mathrm{~m}), 1.57(\mathrm{~m})$ \\
\hline 8 & - & - & - & - \\
\hline 9 & $1.42(\mathrm{~m})$ & $1.38(\mathrm{~m})$ & $1.39(\mathrm{~m})$ & $1.43(\mathrm{~m})$ \\
\hline 10 & - & - & - & - \\
\hline 11 & $1.55(\mathrm{~m}), 1.24(\mathrm{~m})$ & $1.50(\mathrm{~m}), 1.40(\mathrm{~m})$ & $1.51(\mathrm{~m}), 1.19(\mathrm{~m})$ & $1.56(\mathrm{~m}), 1.27(\mathrm{~m})$ \\
\hline 12 & $1.59(\mathrm{~m}), 1.70(\mathrm{~m})$ & $1.71(\mathrm{~m}), 1.58(\mathrm{~m})$ & $1.57(\mathrm{~m}), 1.16(\mathrm{~m})$ & $1.57(\mathrm{~m}), 1.17(\mathrm{~m})$ \\
\hline 13 & $1.71(\mathrm{~m})$ & $1.70(\mathrm{~m})$ & $1.67(\mathrm{~m})$ & $1.68(\mathrm{~m})$ \\
\hline 14 & - & - & - & - \\
\hline 15 & $4.28(\mathrm{t}, 8.6)$ & $4.25(\mathrm{t}, 8.6)$ & $4.25(\mathrm{~d}, 8.5)$ & $4.26(\mathrm{t}, 8.7)$ \\
\hline 16 & $1.89(\mathrm{~m}), 1.68(\mathrm{~m})$ & $1.86(\mathrm{~m}), 1.68(\mathrm{~m})$ & $1.84(\mathrm{~m}), 1.67(\mathrm{~m})$ & $1.85(\mathrm{~m}), 1.68(\mathrm{~m})$ \\
\hline 17 & $2.25(\mathrm{~m})$ & $2.25(\mathrm{~m})$ & $2.24(\mathrm{~m})$ & $2.24(\mathrm{~m})$ \\
\hline 18 & $1.12(\mathrm{~s})$ & $1.07(\mathrm{~s})$ & $1.06(\mathrm{~s})$ & $1.12(\mathrm{~s})$ \\
\hline 19 & $1.06(\mathrm{~s})$ & $0.90(\mathrm{~s})$ & $0.90(\mathrm{~s})$ & $1.07(\mathrm{~s})$ \\
\hline 20 & - & - & - & - \\
\hline 21 & $4.78(\mathrm{~s}), 4.74(\mathrm{~d}, 1.8)$ & $4.78(\mathrm{~s}), 4.74(\mathrm{~s}-\mathrm{like}) 4.76(\mathrm{~d}, 15.5)$ & 4.75 (overlapped) & $4.78(\mathrm{~s}), 4.74$ (s-like) \\
\hline 22 & $2.24(\mathrm{~m}), 2.01(\mathrm{~m})$ & $2.25(\mathrm{~m}), 2.00(\mathrm{~m})$ & $2.24(\mathrm{~m}), 2.01(\mathrm{~m})$ & $2.01(\mathrm{~m}), 2.25(\mathrm{~m})$ \\
\hline 23 & $1.62(\mathrm{~m}), 1.45(\mathrm{~m})$ & $1.63(\mathrm{~m}), 1.44(\mathrm{~m})$ & $2.24(\mathrm{~m}), 2.01(\mathrm{~m})$ & $2.25(\mathrm{~m}), 2.01(\mathrm{~m})$ \\
\hline 24 & $3.38(\mathrm{dd}, 10.6,1.9)$ & $3.38(\mathrm{dd}, 10.5,2.0)$ & $5.60(\mathrm{t}, 7.2)$ & $5.56(\mathrm{t}, 7.2)$ \\
\hline 25 & - & - & - & - \\
\hline 26 & $1.23(\mathrm{~s})$ & $1.22(\mathrm{~s})$ & $4.31(\mathrm{~s})$ & $4.33(\mathrm{~s})$ \\
\hline 27 & $1.17(\mathrm{~s})$ & $1.17(\mathrm{~s})$ & $4.21(\mathrm{~s})$ & $4.22(s)$ \\
\hline 28 & $3.43(\mathrm{~d}, 11.3), 3.64(\mathrm{~d}, 11.3)$ & $1.27(\mathrm{~s})$ & $1.27(\mathrm{~s})$ & $3.65(\mathrm{~d}, 11.3), 3.42(\mathrm{~d}, 11.3)$ \\
\hline 29 & $1.01(\mathrm{~s})$ & $3.98(\mathrm{~d}, 11.2), 3.45(\mathrm{~d}, 11.2)$ & $3.98(\mathrm{~d}, 11.2), 3.45(\mathrm{~d}, 11.2)$ & $1.07(\mathrm{~s})$ \\
\hline 30 & $0.95(\mathrm{~s})$ & $0.96(\mathrm{~s})$ & $0.96(\mathrm{~s})$ & $0.96(\mathrm{~s})$ \\
\hline
\end{tabular}

${ }^{\mathrm{a}}$ Data were measured at $600 \mathrm{MHz}$ in $\mathrm{CDCl}_{3}$

1 were $\delta 3.38 / 78.1$ (H/C-24) indicated that the absolute configuration of C-24 in $\mathbf{1}$ was $S$. Moreover, This conclusion was surpported by the 1D NMR data of the related compound (24S)-24,25-dihydroxy-dammar-20-en-3-one [ $\delta$ 3.39/78.3 (H/C-24)] [15]. Additionally, the OH-15 in $\mathbf{1}$ was assigned to be $\alpha$-oriented by the ROESY correlation of $\mathrm{H}_{3^{-}}$18/H-15 (Fig. 2). Therefore, the structure of 1 was established as (24S)-15 $\alpha, 24,25,28 \alpha$-tetrahydroxy-dammar-20en-3-one.

Caffruone B (2), obtained as white amorphous powder, was assigned the molecular formula $\mathrm{C}_{30} \mathrm{H}_{50} \mathrm{O}_{5}$ by HRESIMS, as the same as $\mathbf{1}$. Moreover, its ${ }^{1} \mathrm{H}$ and ${ }^{13} \mathrm{C}$ NMR spectra (Tables 1,2 ) were nearly superimposable with those of $\mathbf{1}$, which indicated that they had the same planer structure. However, detailed analysis of the 2D NMR spectra showed that the main difference between $\mathbf{1}$ and $\mathbf{2}$ were present in their ROESY spectra. The oxygenated methylene protons $\left(\delta_{\mathrm{H}} 3.98,3.45, \mathrm{H}_{2}-29\right)$ showed correlation of $\beta$-oriented methyl protons $\mathrm{H}_{3}-19\left(\delta_{\mathrm{H}} 0.90\right)$ in 2 , rather than $\mathrm{H}-5 \alpha$ in $\mathbf{1}$, suggesting that $\mathrm{C}-29$ was the oxygenated methylene in $\mathbf{2}$, not $\mathrm{C}-28$ in $\mathbf{1}$. Meanwhile, the ROESY correlation of $\mathrm{H}_{3}-18\left(\delta_{\mathrm{H}} 1.07\right) / \mathrm{H}-15\left(\delta_{\mathrm{H}} 4.25\right)$ proved the $15-\mathrm{OH}$ to be $\alpha$-oriented (supporting infomation). Similarly, the absolute configuration of C-24 in $\mathbf{2}$ was determined as $S$ due to the same chemical shifts of C-24 with $\mathbf{1}$. These results indicated that $\mathbf{1}$ and $\mathbf{2}$ were a pair of epimers. Therefore, $\mathbf{2}$ was elucidated as (24S)$15 \alpha, 24,25,29 \beta$-tetrahydroxy-dammar-20-en-3-one.

Caffruone $\mathrm{C}(\mathbf{3})$ was isolated as white amorphous powder. Its molecular formula, $\mathrm{C}_{30} \mathrm{H}_{48} \mathrm{O}_{5}$, determined from 
Table $2{ }^{13} \mathrm{C}$ NMR spectroscopic data of compounds $\mathbf{1 - 4}[\delta$ in ppm]

\begin{tabular}{|c|c|c|c|c|}
\hline Position & $1^{a}$ & $2^{a}$ & $3^{\mathrm{a}}$ & $4^{a}$ \\
\hline 1 & $39.6(t)$ & $39.7(t)$ & $39.7(\mathrm{t})$ & $39.6(t)$ \\
\hline 2 & $35.3(\mathrm{t})$ & $34.2(\mathrm{t})$ & $34.2(\mathrm{t})$ & $35.2(\mathrm{t})$ \\
\hline 3 & $219.0(\mathrm{~s})$ & $221.3(\mathrm{~s})$ & $221.4(\mathrm{~s})$ & $219.0(\mathrm{~s})$ \\
\hline 4 & $52.4(\mathrm{~s})$ & $50.8(\mathrm{~s})$ & $50.8(\mathrm{~s})$ & $52.5(\mathrm{~s})$ \\
\hline 5 & $49.3(d)$ & $55.5(\mathrm{~d})$ & $55.5(\mathrm{~d})$ & 49.3 (d) \\
\hline 6 & $19.0(\mathrm{t})$ & $19.0(\mathrm{t})$ & $19.0(\mathrm{t})$ & $19.0(\mathrm{t})$ \\
\hline 7 & $35.4(\mathrm{t})$ & $35.4(\mathrm{t})$ & $35.5(\mathrm{t})$ & $35.5(\mathrm{t})$ \\
\hline 8 & $40.7(\mathrm{~s})$ & $40.5(\mathrm{~s})$ & $40.5(\mathrm{~s})$ & $40.5(\mathrm{~s})$ \\
\hline 9 & $50.5(\mathrm{~d})$ & $50.5(\mathrm{~d})$ & $50.4(d)$ & 50.5 (d) \\
\hline 10 & $36.8(\mathrm{~s})$ & $36.6(\mathrm{~s})$ & $36.6(\mathrm{~s})$ & $36.6(\mathrm{~s})$ \\
\hline 11 & $21.6(\mathrm{t})$ & $22.1(\mathrm{t})$ & $22.2(\mathrm{t})$ & $22.2(\mathrm{t})$ \\
\hline 12 & $24.7(\mathrm{t})$ & $24.8(\mathrm{t})$ & $24.8(\mathrm{t})$ & $24.8(\mathrm{t})$ \\
\hline 13 & $43.6(d)$ & $43.6(d)$ & 43.4 (d) & 43.4 (d) \\
\hline 14 & $50.4(\mathrm{~s})$ & $50.4(\mathrm{~s})$ & $50.3(\mathrm{~s})$ & $50.4(\mathrm{~s})$ \\
\hline 15 & 73.8 (d) & 73.8 (d) & 73.8 (d) & 73.8 (d) \\
\hline 16 & $38.6(t)$ & $38.6(t)$ & $38.4(\mathrm{t})$ & $38.5(t)$ \\
\hline 17 & $45.5(d)$ & $45.5(d)$ & 45.2 (d) & 45.2 (d) \\
\hline 18 & $15.6(q)$ & $15.1(q)$ & $15.0(q)$ & $15.6(q)$ \\
\hline 19 & $16.1(q)$ & $17.2(q)$ & $17.2(q)$ & $16.0(q)$ \\
\hline 20 & $151.6(\mathrm{~s})$ & $151.5(\mathrm{~s})$ & $150.7(\mathrm{~s})$ & $150.8(\mathrm{~s})$ \\
\hline 21 & $108.5(\mathrm{t})$ & $108.4(\mathrm{t})$ & $108.7(\mathrm{t})$ & $108.7(\mathrm{t})$ \\
\hline 22 & $31.2(\mathrm{t})$ & $31.1(\mathrm{t})$ & $33.8(\mathrm{t})$ & $33.8(\mathrm{t})$ \\
\hline 23 & $29.9(\mathrm{t})$ & $29.9(\mathrm{t})$ & $26.1(\mathrm{t})$ & $26.0(\mathrm{t})$ \\
\hline 24 & 78.1 (d) & 78.1 (d) & $130.4(\mathrm{~d})$ & 130.5 (d) \\
\hline 25 & $73.1(\mathrm{~s})$ & $73.2(\mathrm{~s})$ & $137.3(\mathrm{~s})$ & $137.2(\mathrm{~s})$ \\
\hline 26 & $26.6(q)$ & $26.5(q)$ & $60.0(\mathrm{t})$ & $60.0(\mathrm{t})$ \\
\hline 27 & $23.2(q)$ & $23.1(q)$ & $67.4(\mathrm{t})$ & $64.7(\mathrm{t})$ \\
\hline 28 & $66.8(\mathrm{t})$ & $22.0(q)$ & $22.1(q)$ & $65.7(\mathrm{t})$ \\
\hline 29 & $16.6(q)$ & $65.7(\mathrm{t})$ & $65.7(\mathrm{t})$ & $16.5(q)$ \\
\hline 30 & $9.0(\mathrm{q})$ & $8.9(\mathrm{q})$ & $8.9(\mathrm{q})$ & $9.0(q)$ \\
\hline
\end{tabular}

${ }^{\mathrm{a}}$ Data were measured at $150 \mathrm{MHz}$ in $\mathrm{CDCl}_{3}$

the $[\mathrm{M}+\mathrm{Na}]^{+}$peak at $\mathrm{m} / z 511.3396$ (calcd for 511.3394) in the HRESIMS spectrum, suggesting seven degrees of unsaturation. The ${ }^{1} \mathrm{H}$ NMR spectrum (Table 1) showed the signals for four singlet methyls $\left[\delta_{\mathrm{H}} 0.90,0.96,1.06,1.27\right]$, two olefinic $\left[\delta_{\mathrm{H}} 4.76\right.$ (overlapped, $\left.\mathrm{H}_{2}-21\right) ; \delta_{\mathrm{H}} 5.60(\mathrm{t}$, $J=7.2 \mathrm{~Hz}, \mathrm{H}-24)]$, three oxgenated methylenes $\left[\left(\delta_{\mathrm{H}} 3.98\right.\right.$, 3.45 , each $1 \mathrm{H}, J=11.2 \mathrm{~Hz}, \mathrm{H}-29 \mathrm{a}$ and $\mathrm{H}-29 \mathrm{~b}$ ), $\delta_{\mathrm{H}} 4.31$ (s, $\left.\left.\mathrm{H}_{2}-26\right), \delta_{\mathrm{H}} 4.21\left(\mathrm{~s}, \mathrm{H}_{2}-27\right)\right]$, and one oxgenated methine $\left[\delta_{\mathrm{H}}\right.$ $4.25(\mathrm{t}, J=8.5 \mathrm{~Hz}, \mathrm{H}-15)]$. The ${ }^{13} \mathrm{C}$-DEPT NMR spectra (Table 2) suggested that $\mathbf{3}$ was also a triterpenoid derivative with a total of 30 carbons, assigning to four methyls, thirteen methylenes (three oxgenated and one olefinic), six methines (one oxygenated and one olefinic), and seven quaternary carbons (two olefinic and one ketone carbonyl). Aparting the three degrees ocuppied by two double bonds and a carbonyl, the remaining degrees attributed to a tetracyclic system.

Similar with 1, the key $\mathrm{HMBC}$ correaltions from $\mathrm{H}_{3}-18$ $\left(\delta_{\mathrm{H}} 1.06\right)$ to $\delta_{\mathrm{C}} 50.4(\mathrm{C}-9), \delta_{\mathrm{C}} 35.5(\mathrm{C}-7)$ and $\delta_{\mathrm{C}} 40.5(\mathrm{C}-8)$, from $\mathrm{H}_{3}-19\left(\delta_{\mathrm{H}} 0.90\right)$ to $\delta_{\mathrm{C}} 36.6(\mathrm{C}-10), 39.7(\mathrm{C}-1), \delta_{\mathrm{C}} 50.4$ (C-9) and $\delta_{\mathrm{C}} 55.5(\mathrm{C}-5)$, together with the ROESY correlations of $\delta_{\mathrm{H}} 1.59(\mathrm{H}-7 \mathrm{a}) / \delta_{\mathrm{H}} 0.96\left(\mathrm{H}_{3}-30\right), \delta_{\mathrm{H}} 1.48(\mathrm{H}-7 \mathrm{~b}) /$ $\delta_{\mathrm{H}} 1.06\left(\mathrm{H}_{3}-18\right) / \delta_{\mathrm{H}} 1.67(\mathrm{H}-13)$ confirmed that 3 was also a dammarane triterpenoid.

Based on its 1D and 2D NMR data, 3 was assigned as a 3-oxo-dammara-20,24-dien-26-ol triterpenoid along with three additonal hydroxy groups [18]. The ${ }^{1} \mathrm{H}-{ }^{1} \mathrm{H}$ COSY correlations of $\delta_{\mathrm{H}} 4.25(\mathrm{H}-15) / \delta_{\mathrm{H}} 1.84,1.67\left(\mathrm{H}_{2}-16\right)$ and HMBC correaltion from $\mathrm{H}-15$ to $\delta_{\mathrm{C}} 8.9$ (C-30) comfired that $\mathrm{C}-15$ in 3 was an oxygenated methine. In the HMBC spectrum, the correlations from the oxygenated methylene protons $\delta_{\mathrm{H}} 4.21\left(\mathrm{H}_{2}-27\right)$ to $\delta_{\mathrm{C}} 60.0(\mathrm{C}-26)$ and $\delta_{\mathrm{C}} 137.3(\mathrm{C}-$ $25)$ and from the olefinic proton $\delta_{\mathrm{H}} 5.60(\mathrm{H}-24)$ to $\delta_{\mathrm{C}} 67.4$ (C-27) deduced that C-27 in $\mathbf{3}$ was substituted by a hydroxy group. Moreover, the ROESY correlations of $\delta_{\mathrm{H}} 3.98,3.45$ $\left(\mathrm{H}_{2}-29\right) / \delta_{\mathrm{H}} 0.90\left(\mathrm{H}_{3}-19\right)$ and $\mathrm{HMBC}$ correlations from $\mathrm{H}_{2}-$ 29 to $\delta_{\mathrm{C}} 22.1(\mathrm{C}-28), \delta_{\mathrm{C}} 50.8(\mathrm{C}-4)$ and $\delta_{\mathrm{C}} 221.4(\mathrm{C}-3)$ demonstrated that $\mathrm{C}-29$ in $\mathbf{3}$ was also substituted by a hydroxy group (Fig. 3). Furthermore, the relative configuration of $\mathrm{OH}-15$ in 3 was elucidated as $\alpha$-oriented by the ROESY correlation of $\mathrm{H}-15\left(\delta_{\mathrm{H}} 4.25\right) / \mathrm{H}_{3}-18\left(\delta_{\mathrm{H}} 1.06\right)$. Thus, these spectral data established 3 as $15 \alpha, 26,27,29 \beta$ tetrahydroxy-dammar-20,24-dien-3-one.
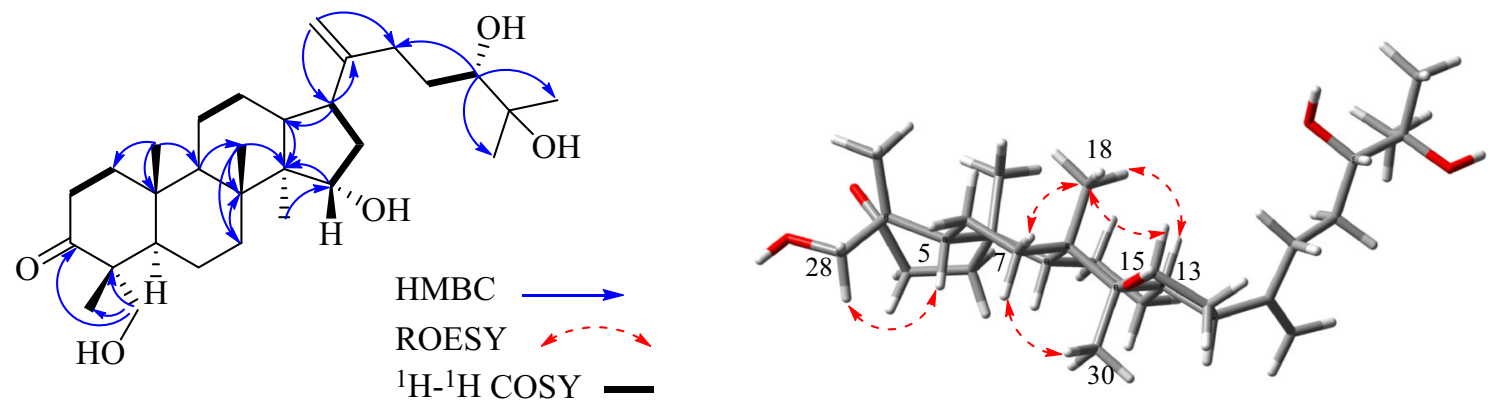

Fig. 2 The key HMBC, ROESY and ${ }^{1} \mathrm{H}^{-1} \mathrm{H}$ COSY correlations of compound $\mathbf{1}$ 

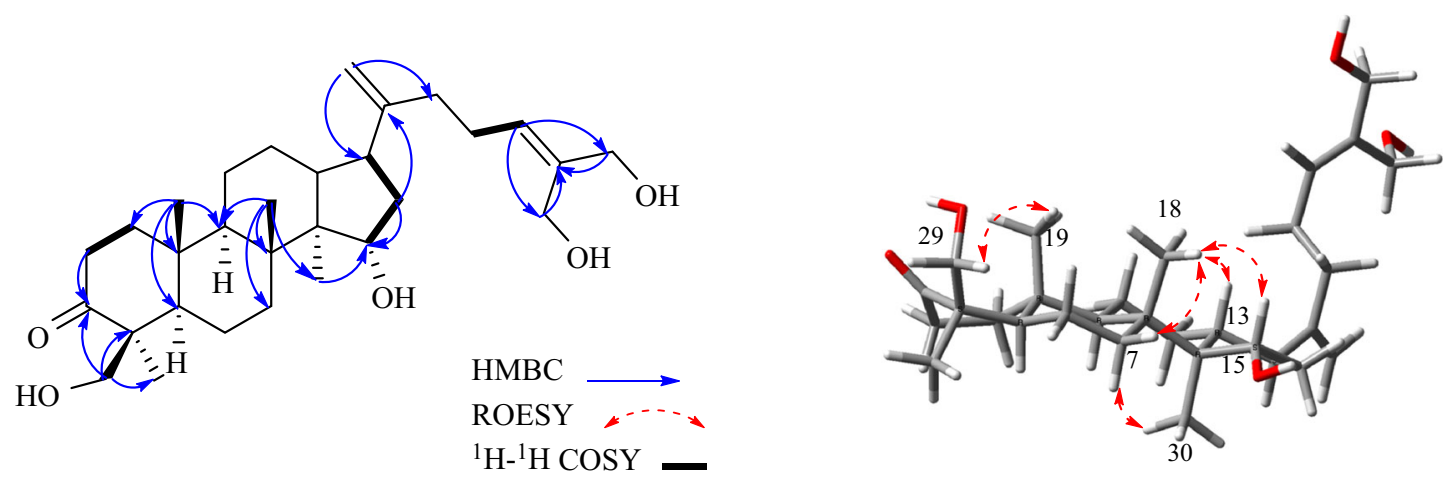

Fig. 3 The key HMBC, ROESY and ${ }^{1} \mathrm{H}^{-1} \mathrm{H}$ COSY correlations of compound 3

Caffruone D (4) was obtained as white amorphous powder and possessed the same molecular formula of $\mathrm{C}_{30} \mathrm{H}_{48} \mathrm{O}_{5}$ as 3 , as determined by HRESIMS data. The 1D NMR data (Tables 1,2) of $\mathbf{3}$ were also observed in $\mathbf{4}$, which indicated that they had the same planar structure. Similarly, the key ROESYcorrelations of an oxygenated methylene protons $\delta_{\mathrm{H}} 3.62,3.42\left(\mathrm{H}_{2}-28\right)$ with $\delta_{\mathrm{H}} 1.43(\mathrm{H}-$ 5) demonstrated that $\mathrm{C}-28$ was oxygenated methylene in $\mathbf{3}$, not C-29 in 4. Moreover, the ROESY correlation of $\delta_{\mathrm{H}} 4.26$ $(\mathrm{H}-15) / \delta_{\mathrm{H}} 1.12\left(\mathrm{H}_{3}-18\right)$ indicated that the OH-15 was $\alpha-$ oriented (supporting information). These evidence suggested that $\mathbf{3}$ and $\mathbf{4}$ was also a pair of epimers. Therefore, the structure of $\mathbf{4}$ was characterized as $15 \alpha, 26,27,28 \alpha$-tetrahydroxy-dammar-20,24-dien-3-one.

\section{Experimental}

\subsection{General Experimental Procedures}

Ultraviolet spectra were measured by UV-2401 PC spectrophotometers (Shimadzu, Japan). A Bruker Tensor-27 instrument (Bruker, German) was used for recording infrared spectra by using $\mathrm{KBr}$ pellets. A Jasco P-1020 polarimeter (Jasco, Japan) was used to obtain optical rotations and HREIMS data were measured by an API QSTAR Pulsar spectrometer (Waters, UK). The Bruker DRX-600 instruments (Bruker, Zurich, Switzerland) were used to detect 1D and 2D NMR spectra with TMS as internal standard for chemical shifts. Semi-preparative HPLC was performed on an Agilent HP1100 or 1260 series instrument with a UV L-2400 detector (Agilent, USA) and an ZORBAX SB C-18 column $\left(5 \mu \mathrm{m}, 9.4 \times 250 \mathrm{~mm}^{2}\right.$, wavelength detection at $210,280 \mathrm{~nm})$. TLC detection was performed on TLC plates (200-250 $\mu \mathrm{m}$ thickness, F254 Si gel 60, Qingdao Marine Chemical, Inc., China). The ordinary column chromatographic materials include Lichroprep RP-18 (40-63 $\mu \mathrm{m}$, Fuji, Japan), Sephadex LH20 (20-150 $\mu \mathrm{m}$, Pharmacia, USA), Silical gel (200-300 mesh, Qingdao Marine Chemical, Inc., China) and Macroporous resin $(0.3-1.25 \mathrm{~mm}$, Mitsubishi Chemical Corporation, Japan). The industrial-grade methanol, chloroform, ethyl acetate, acetone, petroleum ether were purchased from Tianjing Chemical Reagents Co. (Tianjing, China). The analytical-grade acetonitrile were purchased from Aladdin Industrial Corporation (Shanghai, China).

\subsection{Plant Material}

The air-dried cherries of $C$. arabica cultivated in Ruili of Dehong Dai and Jingpo Autonomous Prefecture (Yunnan province, China) were harvested in July 2016 and identified by Hong-bo Zhang, Dehong Institute of Tropical Agriculture. A specimen was deposited in State Key Laboratory of Phytochemistry and Plant Resources in West China, Kunming Institute of Botany, Chinese Academy of Sciences.

\subsection{Extraction and Isolation}

The powder of air-dried Arabica coffee cherries $(24 \mathrm{~kg})$ were extracted by methanol at $80{ }^{\circ} \mathrm{C}$ for three times $(3 \mathrm{~h}$ for each time). The methanol extract was evaporated under reduced pressure. Then, the $2.5 \mathrm{~kg}$ residue was suspended in water and extract with petroleum ether, ethyl acetate (EtOAc) and $n$-butanol, in turn. The EtOAc layer $(200 \mathrm{~g})$ was separated on a macroporous resin column $\left(20.0 \times 120 \mathrm{~cm}^{2}\right)$ and eluted in a step gradient manner with $\mathrm{MeOH} / \mathrm{H}_{2} \mathrm{O}(0: 100,20: 80,40: 60,60: 40,80: 20,100: 0$, v/v) to yield six fractions: Fr. A (10 g), Fr. B (24 g), Fr. C (25 g), Fr. D (38 g), Fr. E (16 g), Fr. F (30 g), respectively. Fr. E (16 g) was then further subjected to silica gel column chromatography $(15.0 \times 80 \mathrm{~cm})$, eluting in a gradient system of $\mathrm{CHCl}_{3} / \mathrm{MeOH}(100: 0 \rightarrow 1: 2, \mathrm{v} / \mathrm{v})$ to yield seven sub-fractions (Fr. E-1-Fr. E-7) on the basis of TLC analysis. Fr. E-3 (2 g) was separated by use of Sephadex LH-20 $(5.0 \times 200 \mathrm{~cm}$, eluted with $\mathrm{MeOH}, 100 \%, 2 \mathrm{~L})$ and divided into three fractions (Fr. E-3-1-E-3-3). After that, Fr. E-3-2 (700 mg) was chromatographed on a silica column 
$\left(\mathrm{CHCl}_{3} / \mathrm{MeOH}\right)$, then separated by reverse-phase semipreparative HPLC $\left(\mathrm{CH}_{3} \mathrm{CN} / \mathrm{H}_{2} \mathrm{O}: 20 \rightarrow 40 \%, 60 \mathrm{~min}\right.$, flow rate $=3.0 \mathrm{~mL} / \mathrm{min}, \mathrm{UV}, 205 \mathrm{~nm})$ to get $1\left(5 \mathrm{mg}, \mathrm{t}_{R-}\right.$ $=51.5 \mathrm{~min})$ and $2\left(10 \mathrm{mg}, \mathrm{t}_{R}=46.1 \mathrm{~min}\right)$. Fr. E-4 (1.6 g) was divided into four minor fractions by use of Sephadex LH-20 $(5.0 \times 200 \mathrm{~cm}$, eluted with $\mathrm{MeOH}, 100 \%, 2 \mathrm{~L})$, then Fr. E-4-3 was applied to RP C-18 $(3.0 \times 70 \mathrm{~cm})$ and eluted in a gradient of $\mathrm{MeOH} / \mathrm{H}_{2} \mathrm{O}(40 \rightarrow 80 \%, \mathrm{v} / \mathrm{v})$ to yield minor fractions, then Fr. E-4-3-2 was treat by reversephase semi-preparative HPLC $\left(\mathrm{CH}_{3} \mathrm{CN} / \mathrm{H}_{2} \mathrm{O}: 20 \rightarrow 40 \%\right.$, $60 \mathrm{~min}$, flow rate $=3.0 \mathrm{~mL} / \mathrm{min}, \mathrm{UV}, 205 \mathrm{~nm}$ ) to gain 3 $\left(9 \mathrm{mg}, \mathrm{t}_{R}=47.3 \mathrm{~min}\right)$ and $4\left(4 \mathrm{mg}, \mathrm{t}_{R}=41.5 \mathrm{~min}\right)$.

\subsection{Spectroscopic Data of Compounds}

\subsubsection{Caffruone A (1)}

White amorphous powder, $[\alpha]_{\mathrm{D}}^{24}+1.8(c=0.09, \mathrm{MeOH})$; $\mathrm{UV}(\mathrm{MeOH}) \lambda_{\max }(\log \varepsilon): 203$ (3.85), $372(2.97) \mathrm{nm}$; IR (KBr) $v_{\max }: 3431,3080,2975,2872,1745,1690,1620$, 1460, 1380, 1000, $906 \mathrm{~cm}^{-1}$; HRESIMS $\mathrm{m} / \mathrm{z} 513.3551$ $[\mathrm{M}+\mathrm{Na}]^{+}$(calcd for $\left.\mathrm{C}_{30} \mathrm{H}_{50} \mathrm{O}_{5} \mathrm{Na}, 513.3550\right) ;{ }^{1} \mathrm{H}$ and ${ }^{13} \mathrm{C}$ NMR data shown in Tables 1 and 2.

\subsubsection{Caffruone B (2)}

White amorphous powder, $[\alpha]_{\mathrm{D}}^{24}-4.8(c=0.2, \mathrm{MeOH})$; $\mathrm{UV}(\mathrm{MeOH}) \lambda_{\max }(\log \varepsilon): 202$ (3.77), 268 (2.86), 374 $(0.0067) \mathrm{nm}$; IR (KBr) $v_{\text {max }}: 3430,3083,2965,2872,1680$, $1610,1460,1380,1010,900 \mathrm{~cm}^{-1}$; HRESIMS $\mathrm{m} /$ $z \quad 513.3551\left[\mathrm{M}+\mathrm{Na}^{+}\right.$(calcd for $\mathrm{C}_{30} \mathrm{H}_{50} \mathrm{O}_{5} \mathrm{Na}$, 513.3550); ${ }^{1} \mathrm{H}$ and ${ }^{13} \mathrm{C}$ NMR data shown in Tables 1 and 2.

\subsubsection{Caffruone C (3)}

White amorphous powder, $[\alpha]_{\mathrm{D}}^{24}-1.9(c=0.2, \mathrm{MeOH})$; $\mathrm{UV}(\mathrm{MeOH}) \lambda_{\max }(\log \varepsilon): 203$ (3.36), 278 (2.39) nm; IR (KBr) $v_{\max }: 3410,3080,2960,2870,1724,1685,1615$, 1460, 1380, 1020, $905 \mathrm{~cm}^{-1}$; HRESIMS $\mathrm{m} / \mathrm{z} 511.3396$ $[\mathrm{M}+\mathrm{Na}]^{+}$(calcd for $\left.\mathrm{C}_{30} \mathrm{H}_{48} \mathrm{O}_{5} \mathrm{Na}, 511.3394\right) ;{ }^{1} \mathrm{H}$ and ${ }^{13} \mathrm{C}$ NMR data shown in Tables 1 and 2.

\subsubsection{Caffruone D (4)}

White amorphous powder, $[\alpha]_{\mathrm{D}}^{24}+18.9(c=0.1, \mathrm{MeOH})$; $\mathrm{UV}(\mathrm{MeOH}) \lambda_{\max }(\log \varepsilon): 203$ (3.89), 269 (2.83) nm; IR (KBr) $v_{\max }: 3420,3080,2970,2880,1690,1610,1460$, 1380, 1020, $920 \mathrm{~cm}^{-1}$; HRESIMS $\mathrm{m} / z \quad 511.3397$ $[\mathrm{M}+\mathrm{Na}]^{+}$(calcd for $\mathrm{C}_{30} \mathrm{H}_{48} \mathrm{O}_{5} \mathrm{Na}, 511.3394$ ); ${ }^{1} \mathrm{H}$ and ${ }^{13} \mathrm{C}$ NMR data shown in Tables 1 and 2 .
Acknowledgements This study was supported financially by the National Natural Science Foundation of China, China (No. 31670364), Project of Key New Productions of Yunnan Province, China (No. 2015BB002), the STS Programme of Chinese Academy of Sciences, China (KFJ-SW-STS-143-8), Special Fund Project of Pu'er municipal government, China (2017), as well as Foundation of State Key Laboratory of Phytochemistry and Plant Resources in West China, China (P2015-ZZ09).

\section{Compliance with Ethical Standards}

Conflict of interest All authors declare no conflict of interest.

Open Access This article is distributed under the terms of the Creative Commons Attribution 4.0 International License (http://creative commons.org/licenses/by/4.0/), which permits unrestricted use, distribution, and reproduction in any medium, provided you give appropriate credit to the original author(s) and the source, provide a link to the Creative Commons license, and indicate if changes were made.

\section{References}

1. International Coffee Organization: Trade statistics tables (2018)

2. X.G. Liu, K. Hao, Z.H. Han, N. Yu, Q.L. Yang, Y.W. Liu, Trans. Chin. Soc. Agric. Machin. 47, 143-150 (2016)

3. M. Varghese, L. Ho, J. Wang, W. Zhao, S. Levine, K. Ono, S. Mannino, G.M. Pasinetti, Trans. Neurosc. 5, 111-116 (2014)

4. Y.F. Chu, Y.M. Chen, P.M. Black, P.H. Brown, B.J. Lyle, R.H. Liu, B.X. Ou, Food Chem. 124, 914-920 (2010)

5. G. Grosso, J. Grodos, F. Galvano, E.L. Giovannucci. Annu. Rev. Nutr. 37, 131-156 (2017)

6. J.L. Shao, X.Y. Liu, D.S. Yang, J.L. Fan, L.J. Du, L. Wang, L.X. Wang, J. Shanxi Agric. Sci. 44, 158-163 (2016)

7. R. Chu, L.S. Wan, X.R. Peng, M.Y. Yu, Z.R. Zhang, L. Zhou, Z.R. Li, M.H. Qiu, Nat. Prod. Bioprospect. 6, 217-223 (2016)

8. I. Wahlberg, C.R. Enzell, J.W. Rome, Phytochemistry 14, 1677 (1975)

9. T. Ranheim, B. Halvorsen, Mol. Nutr. Food Res. 49, 274-284 (2010)

10. A. Nehlig, Pract. Neurol. 16, 89-95 (2015)

11. X.H. Cai, X.D. Luo, J. Zhou, X.J. Hao, Org. Lett. 7, 2877-2879 (2005)

12. H. Zhang, H.H. Xu, Z.J. Song, L.Y. Chen, H.J. Wen, Fitoterapia 83, 1081-1086 (2012)

13. R.B. Boar, K. Damps, J. Chem. Soc. Perkin Trans. 5, 510-512 (1977)

14. Z.L. Hong, J. Xiong, S.B. Wu, J.J. Zhu, J.L. Hong, Y. Zhao, G. Xia, J.F. Hu, Phytochemistry 86, 159-167 (2013)

15. M.L. Kennedy, M. Reyes-Batlle, J. Lorenzo-Morales, J.E. Pinero, I.L. Bazzocchi, I.A. Jimenez, Magn. Reson. Chem. Mrc. 56, 46-54 (2017)

16. M. Ukiya, T. Akihisa, H. Tokuda, K. Koike, J. Takayasu, H. Okuda, Y. Kimura, T. Nikaido, H. Nishino, J. Agric. Food Chem. 51, 2949-2957 (2003)

17. A. Inada, S. Ohtsuki, H. Murata, Y. Inatomi, D. Darnaedi, T. Nakanishi, Phytochemistry 46, 379-381 (1997)

18. H. Chávez, A. Estévez-Braun, R. Ángel, A.G. González, Tetrahedron 53, 6465-6472 (1997) 